\title{
P05.22. Health beliefs and experiences of patients with chronic Lyme disease: a qualitative study
}

\author{
A Ali ${ }^{1 *}$, J Millet ${ }^{1}$, L Vitulano ${ }^{1}$, R Lee ${ }^{2}$, E Colson $^{1}$ \\ From International Research Congress on Integrative Medicine and Health 2012 \\ Portland, Oregon, USA. 15-18 May 2012
}

\section{Purpose}

Chronic Lyme disease is a term that describes a constellation of persistent symptoms in patients who may or may not have serologic evidence of Borrelia burgdorferi infection. Little has been published in the medical literature about patients with chronic Lyme disease or their relationships with healthcare providers. The objective of this study was to gain insights into the health beliefs and experiences of patients with chronic Lyme disease.

\section{Methods}

This was a qualitative, descriptive study in which face-toface in-depth interviews were conducted with patients who were diagnosed with or self-identify as having chronic Lyme disease. Patients were recruited through Connecticut-based Lyme disease mailing lists and support groups. A coding structure was developed using an iterative process. Transcribed interviews were coded using Atlas.ti software and analyzed for emergent topics and themes. Interviews were conducted until thematic saturation was achieved.

\section{Results}

A total of 12 interviews were conducted. Four major themes emerged. Patients reported: (1) diminished health status associated with chronic Lyme disease; (2) concerns about persistence of symptoms (e.g., that full recovery was unlikely); (3) two divergent types of physician-patient relationships (i.e., exceptionally supportive or uncaring and dismissive); and (4) seeking and receiving unconventional care (e.g., complementary/alternative therapies and/or prolonged treatment with antibiotics).

${ }^{1}$ Yale University School of Medicine, New Haven, USA

Full list of author information is available at the end of the article

\section{Conclusion}

Our findings show that patients report a marked decrease in health status associated with chronic Lyme disease and are often unsatisfied with care in conventional settings. Negative experiences with providers were associated with reports of dismissive, patronizing, or condescending attitudes. Positive experiences were associated with providers reported to be attentive, optimistic, and supportive. Patient-centered approaches that acknowledge suffering and focus on continuity of care and symptomatic relief may result in increased patient satisfaction.

\section{Author details}

${ }^{1}$ Yale University School of Medicine, New Haven, USA. ${ }^{2}$ National College of Natural Medicine, Portland, USA.

Published: 12 June 2012

doi:10.1186/1472-6882-12-S1-P382

Cite this article as: Ali et al.: P05.22. Health beliefs and experiences of patients with chronic Lyme disease: a qualitative study. BMC Complementary and Alternative Medicine 2012 12(Suppl 1):P382.

Submit your next manuscript to BioMed Central and take full advantage of:

- Convenient online submission

- Thorough peer review

- No space constraints or color figure charges

- Immediate publication on acceptance

- Inclusion in PubMed, CAS, Scopus and Google Scholar

- Research which is freely available for redistribution
C Biomed Central

() 2012 Ali et al; licensee BioMed Central Ltd. This is an Open Access article distributed under the terms of the Creative Commons Attribution License (http://creativecommons.org/licenses/by/2.0), which permits unrestricted use, distribution, and reproduction in any medium, provided the original work is properly cited. 